Bulletin de la Société Royale des Sciences de Liège, Vol. 86, special edition, 2017, p. 908 - 918

\title{
The Impact of Drama-Based Instruction as Effective Language Learning Strategies on Improving Primary Iranian ESL Learners' Speaking Abilities
}

\author{
Pooneh KARIMZADEH \\ Department of English language, Payame Noor University, I. R. of Iran \\ pooneh.karimzadeh@gmail.com
}

\begin{abstract}
The present article investigates the significant effect of drama-based techniques as language learning strategies that can improve communicative competence to achieve appropriate level of speaking abilities. As a matter of fact drama based strategies are similar to that of language learning strategies that both as pedagogical tools deal with improving high order thinking skills that result in learner's self-control and facilitate the internalization, storage, retrieval and interaction in the process of accomplishing well-grounded speaking tasks. In order to investigate this study, a total of 60 primary school children in third to sixth grade in private English Institute in Iran, take Ket Movers Exam. 30 homogeneous students are chosen and are divided in two groups, 15 in experimental who receive treatment and the other in control group. Data analysis presents the significant role of using drama-based strategies as beneficial learning strategies for developing communicative ability.
\end{abstract}

Keywords: drama, language learning strategies, role play, communicative competence

\section{INTRODUCTION}

Because of increasing day to day quick growth of technology all around the world and Iran and a great wave of interest in learning English as an international language, using effective strategies to improve EFL learners' speaking abilities seems fundamental. With respect to this point that those who start learning a second language in childhood are more successful learners than those who start later. (Krashen, long, and Scarcella,1982).It can be concluded that doing some ground work that lead to young learner's better communication training in class seems necessary. Trainers should motivate his learners by applying dynamic, creative, meaningful and cheerful English class. For this reason teacher has a crucial role in applying appropriate style of teaching. Teacher is a little artist who designs the scene of the teaching process and trains great educators. However, drama-based instruction consists of significant strategies through which the laborious process of teaching and learning seem elegant. It is art and art manifest the beauty of life (P.karimzadeh, 2015), no matter where it is. So this paper presents the effect of drama-based techniques as effective metacognitive learning strategies on developing speaking abilities of young Iranian ESL learners. 


\subsection{Background and purpose}

Speaking is one of the four macro skills which is a kind of productive skills and it is more than knowing just some grammatical rules on vocabulary. In order to take part in a normal ESL conversation and keep the interaction properly, a trainer needs various types of techniques. In other words a learner should have enough knowledge of language competence and communicative competence.(A.Ika Handyonil, 2013) . According to Hymes(1972) "The goal of language teaching is to develop communicative competence." For Hymes when a learner acquires communicative competence, elicits knowledge and ability for language use. In another study by Henry Widdowson (1978) there is a relationship between linguistic system and communicative values in text and discourse. In 1980, Canale and Swain presented the four dimensions of communicative competence.

\begin{tabular}{|l|l|l|}
\hline $\begin{array}{c}\text { Canale and Swain } \\
\text { dimensions of four } \\
\text { communicative } \\
\text { competence }\end{array}$ & Grammatical competence & It is grammatical and lexical domain \\
\cline { 2 - 3 } & Strategic competence & $\begin{array}{l}\text { It refers to social context and purpose for } \\
\text { interaction }\end{array}$ \\
\cline { 2 - 3 } & Discourse competence & It refers to interpretation of indirect message \\
\cline { 2 - 3 } & $\begin{array}{l}\text { Sociolinguistic } \\
\text { competence }\end{array}$ & $\begin{array}{l}\text { It refers to those strategies which control the ways } \\
\text { Learners initiate, terminate, maintain and repair the } \\
\text { communication. }\end{array}$ \\
\hline
\end{tabular}

Figure 1 shows that these four dimensions are representative of the underlying speaking proficiency. In respect to this study, it can be concluded that to achieve the communicative goal properly, an EFL learner needs to improve his communicative competence. In this phase the role of a teacher as a leader and supporter is crucial. An experienced teacher tries to use effective language learning strategies to pave the way for communicative competence improvement and foster the learners' communicative abilities. According to Oxford (1990, in Cohen \& Wearer, 1998) there are four categories of language learning strategies: cognitive strategies, metacognitive strategies, affective strategies and social strategies.

The cognitive strategies deals with memory enhancing, retention and retrieved. The metacognitive strategies as indirect learning strategies deal with planning, evaluation, seeking opportunities, controlling anxiety, increasing cooperation and empathy (Huang, 2006).It can also regulate thinking and learning (Brown, 1987;Nelson,1996):planning, monitoring, evaluating. The affective strategies regulate emotions, attitude and motivation and the social strategies which based on the research by Norimah Mohammad and Kuldip Kaur (2013) is more beneficial and significant compared to the metacognitive and affective strategies in speaking. Social strategies refer to techniques that learners use in order to interact with other English speakers. With respect to the significant role of language learning strategies as reliable pedagogical tools, teachers can take advantage of them in a way that make student more active in learning and guide them to monitor and control their learning. (Fig.1.) 


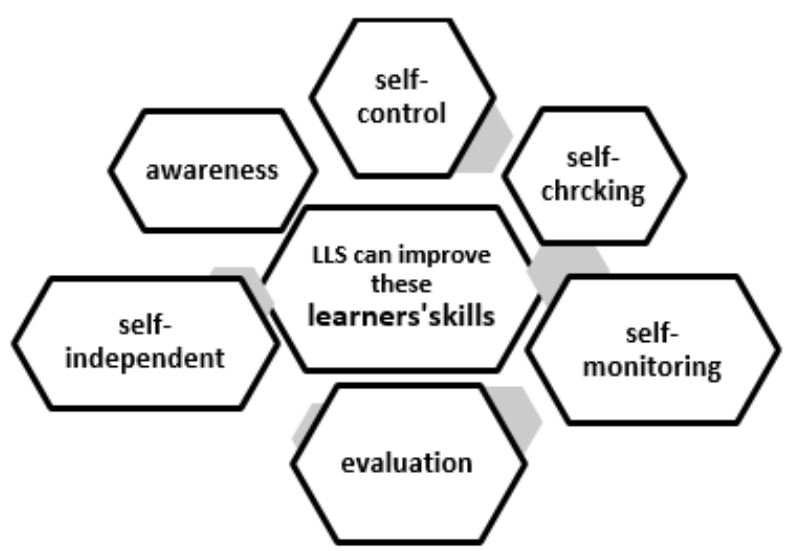

Fig. 1

Drama based instructions consist of various significant techniques that can be helpful for both teachers and students. Moreover via these beneficial techniques the laborious process of learning and teaching won't be a great task. According to Lev Vygotsky (1869-1934) starting point of classroom teaching consists of explicit teacher instruction on one hand and guided practice of cognitive and metacognitive strategies on the other hand that gradually leads to students' independency, self-monitoring, and new strategies capability, self-regulation and ability of taking their own responsibility. For theses reason on the basis of studies by Katlie Dawson (2016) drama based learning strategies as creative- drama or drama-in-education, at first was used in the United States in 1920.After that gradually other countries tried to apply them. According to Mandi Moor (2004) historically drama have been a successful way of teaching .Furthermore drama based strategies are guided, on-exhibition, process centered form of drama which deal with problem solving and creative thinking through creation of kinesics and interactive experience. Based on the study by Rosalind M. Flynn (2012) drama teaching and learning methods encourage not only creative thinking, but also deals with brain based learning principles such as language learning strategies. In regard to the valuable description of play by Lev Vygotsky (1896-1934):

"In play, a child is always above his average age, above his daily behavior; in play, it is as though he were a head taller than himself."

Children by taking role in a play can achieve a simple level of the real life task. It another word when teacher prepare a scenario based on a short dialogue between a doctor and a patient, a learner depict herself in an imaginary situation. (Holden, 1981). 


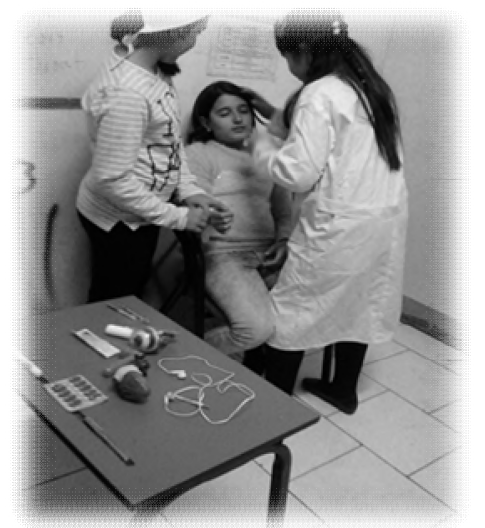

Fig. 2: A learner depict herself in an imaginary situation

\subsection{Statement of the problem}

In spite of the teacher attempts at drawing the learner's attention toward speaking English, unfortunately some of the students don't have strong will to use their communicative skills in their English classes and apply their mother tongue more than their second language. There are different reasons for this situation. According to Gaudart (1992) one of the reason of low learners' participation can be inability to apply oral communication properly. In another place Gaudart has mentioned that lack of learner's motivation can affect this situation. More over in Iran, English is not used in learners' everyday language and they practice it just in their English classes twice or three times a week. With respect to this reasons to achieve the acceptable degree of communicative skills, they need more practice. Based on the study by Liu and Littlewood (1997), the more learners practice language, the more they can use their communicative skills. On the other hand factors such as culture, anxiety, and fear of peer reaction and L1 transfer affect learners' willing to take part in oral communication a lot. Concerning the problem stated above, the following questions projected:

Q1: Do drama-Based Instructions as effective language learning strategies have any effect on improving primary Iranian ESL learners' speaking abilities?

Based on the research question mentioned above, the following hypothesis is proposed:

H01: Drama-Based Instructions as effective language learning strategies don't have any effect on improving primary Iranian ESL learners'speaking abilities.

\section{Review of literature}

\subsection{What is drama?}

Drama refers to any story that can be told in a dialogue and concludes different characters. Furthermore it is a significant tool to present human feeling. Drama increase cognitive, affective and motor development. Drama as a kind of pedagogical tool can be used in different ways in 
Bulletin de la Société Royale des Sciences de Liège, Vol. 86, special edition, 2017, p. 908 - 918 primary English classes such as improvisation, roleplays, mime, masked drama, puppet plays, performance poetry and radio drama.

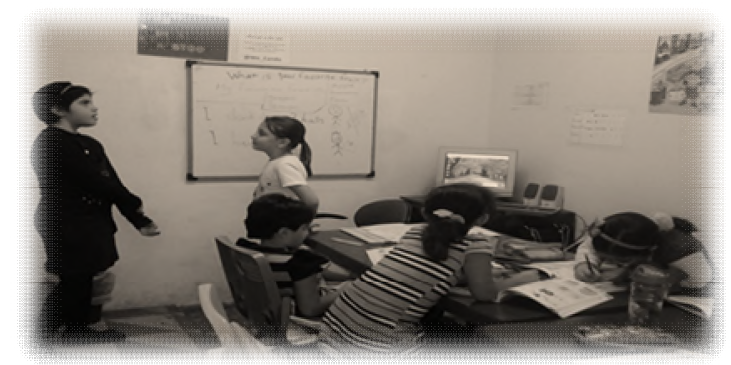

Fig. 3: Role play

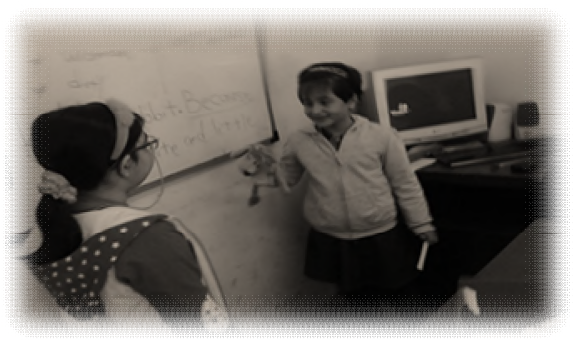

Fig. 4: Dialogue practice

\subsection{Why is drama?}

As far as the young learners are concerned drama script are based on short enjoyable and interesting dialogues which consist of daily life activities and real life situations.

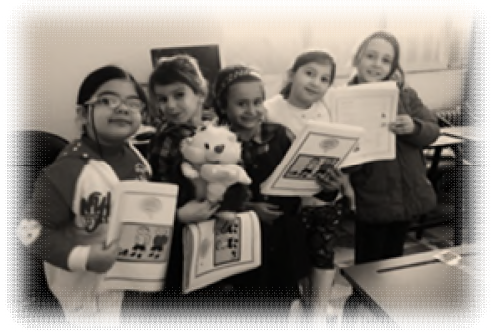

Fig.5 : Drama script are based on short enjoyable and interesting dialogues

\subsection{Role play and drama}

According to Chris Boudreult (2010) role-play as a powerful teaching tool can be beneficial in different ways as follows: 
Bulletin de la Société Royale des Sciences de Liège, Vol. 86, special edition, 2017, p. 908 - 918

\begin{tabular}{|l|l|}
\hline \multirow{4}{*}{$\begin{array}{l}\text { Drama a } \\
\text { Role-play }\end{array}$} & 2.encouraging cooperation \\
\cline { 2 - 2 } & 2.encouraging team work and group work \\
\cline { 2 - 2 } & 3.decision making \\
\cline { 2 - 2 } & 4.exchanging knowledge freely \\
\cline { 2 - 2 } & 5.building self-esteem \\
\cline { 2 - 2 } & 6.encouraging self-acceptance \\
\cline { 2 - 2 } & 7.encouraging acceptance of others \\
\cline { 2 - 2 } & 8.providing real-life condition \\
\hline
\end{tabular}

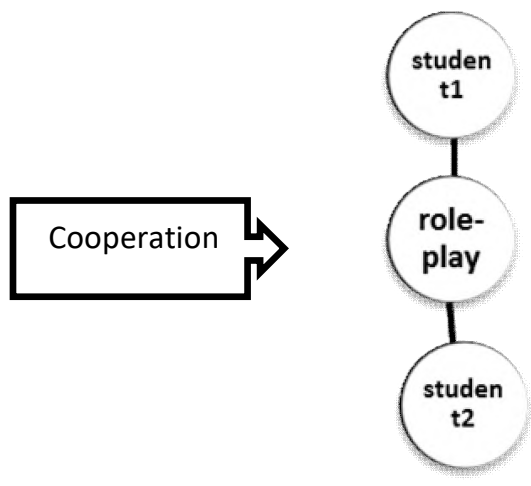

Fig. 6: Role-play is a powerful tool in teaching

\subsection{Significant of drama based instructions}

Theoretical and interactive drama -based methods provide a non-threatening and safe condition for learners. Unlike more traditional learning methods drama can not only involve all the learners' senses, but also provide a safe environment where learners can interact with each other in real life situations easily. Dr. Rosalind M.F. (2012) has proposed 10 powerful benefits of using drama in the classroom which on one hand are brain-based learning principles, and on the other hand cover learners' emotions and movements.

\begin{tabular}{|l|l|}
\hline According to & 1. Student Engagement \\
\cline { 2 - 2 } $\begin{array}{l}\text { Dr.Rosalin M. } \\
\text { (2012) these }\end{array}$ & 2. Collaboration and \\
\cline { 2 - 2 } $\begin{array}{l}\text { are 10 benefits } \\
\text { of using drama }\end{array}$ & Cooperation \\
\cline { 2 - 2 } In classroom: Active Learning & 4. Creativity within Limits \\
\cline { 2 - 2 } & 5. Flexibility \\
\cline { 2 - 2 } & 6. Investment in Learning \\
\cline { 2 - 2 } & 7. Higher Order Thinking Skills \\
\cline { 2 - 2 } & 8. Showing Appreciation \\
\cline { 2 - 2 } & 9. Fun \\
\hline & 10. Discipline. \\
\hline
\end{tabular}

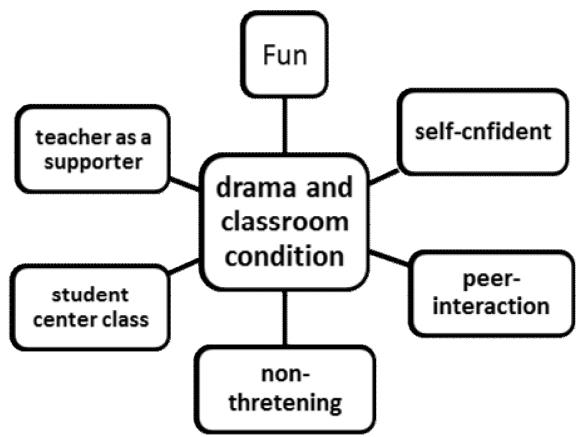

Fig. 7: Benefits of using drama in the classroom 
Bulletin de la Société Royale des Sciences de Liège, Vol. 86, special edition, 2017, p. 908 - 918

\section{Methodology}

The purpose of the study is to investigate the impact of drama-based instruction as effective language learning strategies on improving primary Iranian ESL learners' Speaking Abilities.

\subsection{Participants}

A total of 60,2th to6th primary school student in a private English institute in Iran, take Ket movers exam.30 homogeneous students are chosen and are divided in two groups, 15 in experimental who receive treatment and the other in control group. They participate in speaking class based on drama activities one and a half hour per week for two months in the summer.

\subsection{Instrumentation}

An amusing story with a simple plot is worked every session which its char actors are among children's favorite char actors. Every session on one hand, students role play the dialogue, on the other hand take role and perform the story based on drama -based instructions which are provided by the teacher. The name of the story is "Students in Space" by Craig Wright from Dolphin Reader Oxford university press which consists of almost 400 words and fantastic characters.

\subsection{Data collection and procedures}

The starting point of the speaking class is talking about topic. Teacher brain storm and writes students' answer on the board. After that teacher asks some general questions about the content of the drama script as a warm up and students think about these questions in their group and answer. During this discussion phase teacher provide a plenty of appropriate knowledge of content of the text and some new vocabularies. Being prepared, students become ready for reading and comprehending the text. Teacher asks learners to read the dialogue silently at first and then give them role to read each role loudly and at the last phase ask students to close their book and try to remember whatever they have practiced. They take role and play the dialogue two by two or in a group based on the drama dialogue. Teacher record their performances and ask them to listen to it and correct their pronunciation, intonation, grammar, accent and fluency. As posttest the three teachers and the institute supervisor record students' voice of two experimental and control group in observation and interview session based on the taught story's content, pictures. After that they investigate the result together.

\section{Discussion and analysis}

This study is an attempt to investigate the effect of drama-based instruction on the improvement of the speaking ability of primary EFL learners. To achieve these goals the following research question and its null-hypothesis were proposed;

Q1: Do drama-based instructions as effective Language Learning Strategies have any effect on Improving primary Iranian ESL learners' Speaking Abilities? 
H01: Drama-based instructions as effective Language Learning Strategies don't have any effect on Improving primary Iranian ESL learners' Speaking Abilities.

The data were analyzed through one-way analysis of covariance has four main assumptions; normality, homogeneity of variances of the groups, homogeneity of regression slopes and linear relationship between the covariate and the dependent variable. The latter three assumptions will be discussed when reporting the main results. It should be mentioned that the present data enjoyed normal distribution. The ratios of skewness and kurtosis over their respective standard errors were lower than $+/-1.96$ (Table 1).

Table 1: Descriptive Statistics; Testing Normality Assumption

\begin{tabular}{|c|c|c|c|c|c|c|c|c|}
\hline \multirow[b]{2}{*}{ Group } & & \multirow{2}{*}{$\frac{\mathrm{N}}{\text { Statistic }}$} & \multicolumn{3}{|c|}{ Skewness } & \multicolumn{3}{|c|}{ Kurtosis } \\
\hline & & & Statistic & Std. Error & Ratio & Statistic & Std. Error & Ratio \\
\hline \multirow{2}{*}{ Experimental } & Pretest & 15 & -.169 & .580 & -0.29 & -1.423 & 1.121 & -1.27 \\
\hline & Posttest & 15 & -.764 & .580 & -1.32 & -.693 & 1.121 & -0.62 \\
\hline \multirow{2}{*}{ Control } & Pretest & 15 & -.450 & .580 & -0.78 & -1.197 & 1.121 & -1.07 \\
\hline & Posttest & 15 & -.182 & .580 & -0.31 & -1.042 & 1.121 & -0.93 \\
\hline
\end{tabular}

As it was mentioned above ANCOVA assumes homogeneity of variances of the groups, homogeneity of regression slopes and linear relationship between the covariate and the dependent variable. The results of the Levene's test $(\mathrm{F}(1,28)=5.36, \mathrm{p}=.028)$ indicated that the assumption of homogeneity of variances was violated. However, as noted by Bachman (2015), Pallant (2011) and Field (2013) when sample sizes are equal, as is the case in this study, the violation of this assumption can be ignored.

Table 2: Levene's Test of Equality of Error Variances

\begin{tabular}{llll}
\hline $\mathrm{F}$ & $\mathrm{df1}$ & $\mathrm{df} 2$ & Sig. \\
\hline 5.369 & 1 & 28 & .028 \\
\hline
\end{tabular}

There was a linear relationship between the dependent variable (posttest) and the covariate (pretest). The results of the linearity test $(\mathrm{F}(1,19)=38.36, \mathrm{p}=.000)$ indicated that the statistical null-hypothesis that the relationship between the two variables was not linear was rejected.

Table 3: ANOVA Table; Testing Linear Relationship between Dependent Variable and

Covariate

\begin{tabular}{|c|c|c|c|c|c|c|}
\hline & & Sum of Squares & $\mathrm{df}$ & Mean Square & $\mathrm{F}$ & Sig. \\
\hline \multirow{5}{*}{ Posttest $*$ Pretest } & (Combined) & 2030.500 & 20 & 101.525 & 2.718 & .063 \\
\hline & Between Linearity & 1433.117 & 1 & 1433.117 & 38.368 & .000 \\
\hline & Uroups Deviation from Linearity & 597.383 & 19 & 31.441 & .842 & .643 \\
\hline & Within Groups & 336.167 & 9 & 37.352 & & \\
\hline & Total & 2366.667 & 29 & & & \\
\hline
\end{tabular}

The assumption of homogeneity of regression slopes also was retained. The non-significant interaction between the independent variable and covariate $\left(F(1,26)=.311, p=.582\right.$, partial $\mu^{2}$ $=.012$ representing a weak effect size) indicated that the assumption of homogeneity of regression slopes were met. 
Bulletin de la Société Royale des Sciences de Liège, Vol. 86, special edition, 2017, p. 908 - 918

Table 4: Tests of Between-Subjects Effects; Testing Assumption of Homogeneity of Regression Slopes

\begin{tabular}{ccccccc}
\hline Source & $\begin{array}{c}\text { Type III Sum } \\
\text { of Squares }\end{array}$ & df & Mean Square & F & Sig. & $\begin{array}{c}\text { Partial Eta } \\
\text { Squared }\end{array}$ \\
\hline Group & .121 & 1 & .121 & .006 & .938 & .000 \\
Pretest & 1127.972 & 1 & 1127.972 & 57.417 & .000 & .688 \\
Group * Pretest & 6.113 & 1 & 6.113 & .311 & .582 & .012 \\
Error & 510.777 & 26 & 19.645 & & & \\
Total & 232930.000 & 30 & & & & \\
\hline
\end{tabular}

Based on the results displayed in Table 4; it can be concluded that the experimental group $(\mathrm{M}=$ 91.45, $\mathrm{SE}=1.13,95 \% \mathrm{CI}[89.11,93.78])$ had a higher mean on the posttest of speaking than the control group $(\mathrm{M}=83.88, \mathrm{SE}=1.13,95 \% \mathrm{CI}[81.54,86.21])$ after controlling for the possible effects of pretest.

Table 5: Descriptive Statistics; Posttest of Speaking by Group with Pretest

\begin{tabular}{lllll}
\hline \multirow{2}{*}{ Group } & \multirow{2}{*}{ Mean } & \multirow{2}{*}{ Std. Error } & \multicolumn{2}{l}{$95 \%$ Confidence Interval } \\
\cline { 4 - 5 } & & & Lower Bound & Upper Bound \\
\hline Experimental & $91.451^{\mathrm{a}}$ & 1.138 & 89.115 & 93.786 \\
Control & $83.883^{\mathrm{a}}$ & 1.138 & 81.547 & 86.219 \\
\hline
\end{tabular}

a. Covariates appearing in the model are evaluated at the following values:

Pretest $=80.73$.

The results of ANCOVA $\left(F(1,27)=21.76, p=.000\right.$, partial $\mu^{2}=.446$ representing a large effect size) indicated that there was a significant difference between the experimental and control groups' means on the posttest of speaking after controlling for the possible effects of their entry speaking ability as tested through the pretest. Thus the null-hypothesis was rejected.

Table 6: Tests of Between-Subjects Effects; Posttest of Speaking by Group with Pretest

\begin{tabular}{llllllll}
\hline Source & $\begin{array}{l}\text { Type III Sum } \\
\text { of Squares }\end{array}$ & df & Mean Square & F & Sig. & $\begin{array}{l}\text { Partial } \\
\text { Squared }\end{array}$ & Eta \\
\hline Pretest & 1139.243 & 1 & 1139.243 & 59.509 & .000 & .688 \\
Group & 416.659 & 1 & 416.659 & 21.764 & .000 & .446 \\
Error & 516.890 & 27 & 19.144 & & & \\
Total & 232930.000 & 30 & & & & \\
\hline
\end{tabular}

The significant value associated with the pretest of speaking $(\mathrm{F}=59.50, \mathrm{p}=.000)$ indicated that it was correctly selected as a covariate. 


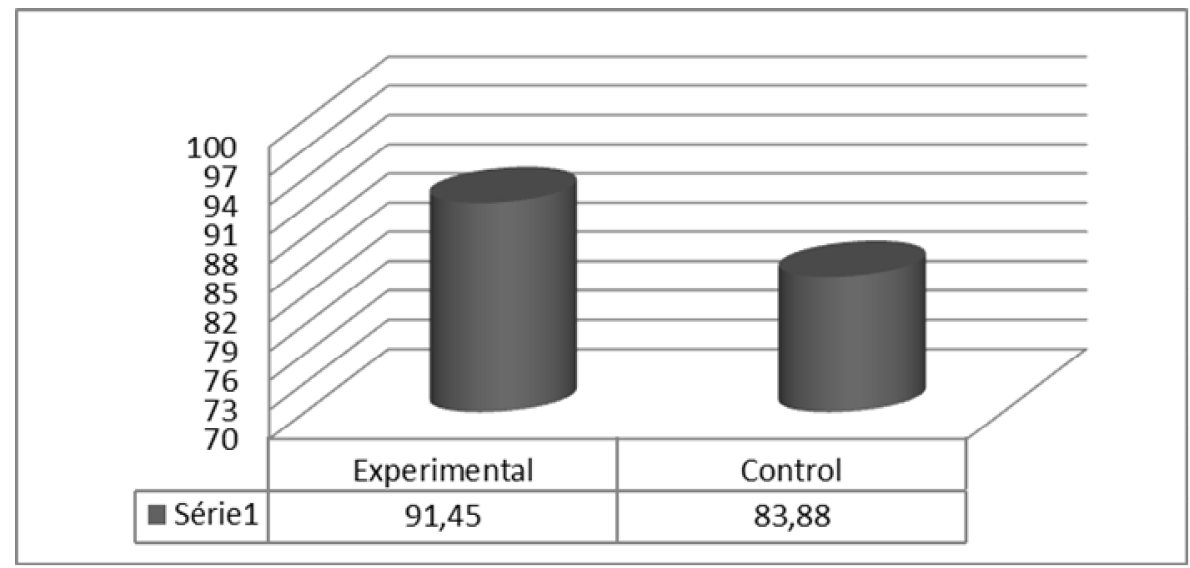

Figure 8: Means on posttest by groups with pretest

The results of the inter-rater reliability indicated that there were significant agreement between the two raters who rated the subjects on the pretest $(\mathrm{r}(28)=.83, \mathrm{p}=.000$ representing a large effect size) and posttest of speaking $(\mathrm{r}(28)=.84, \mathrm{p}=.000$ representing a large effect size) (Table 8).

Table 7: Pearson Correlations; Inter-Rater Reliability

\begin{tabular}{|c|c|c|c|}
\hline & & PreR2 & PostR2 \\
\hline \multirow{3}{*}{ PreR1 } & Pearson Correlation & $.833^{* * *}$ & \\
\hline & Sig. (2-tailed) & .000 & \\
\hline & $\mathrm{N}$ & 30 & \\
\hline \multirow{3}{*}{ PostR1 } & Pearson Correlation & & $.843^{* * *}$ \\
\hline & Sig. (2-tailed) & & .000 \\
\hline & $\mathrm{N}$ & & 30 \\
\hline
\end{tabular}

\section{Conclusion}

This study presented the investigation of the impact of drama- based instruction on the improvement of the speaking ability of primary EFL learners. A total of 60 primary school children in third to sixth grade in private English Institute in Iran, took Ket Movers Exam. 30 homogeneous students were chosen and divided in two groups, 15 in experimental who received treatment and the other in control group. They participated in speaking class based on drama activities one and a half hour per week for two months in the summer. After two months students took posttest based on observation and interview that all were recorded .The results of the research analysis confirmed the idea that using significant drama-based techniques as language learning strategies can be beneficial and supportive. Drama -based instructions as appropriate pedagogical tools can shed light on speaking abilities of primary English learners' in Iran. Through the use of creative elegant drama -based strategies, teacher as a supporter and a friend involve the students in different enjoyable real life tasks and improve their communication skills deliberately. 
Bulletin de la Société Royale des Sciences de Liège, Vol. 86, special edition, 2017, p. 908 - 918

\section{REFERENCE}

[1]

Anita E. W.,

Philip H.W., \& Nancy E.P.(2011).Educational Psychology ( $2^{\text {nd }}$ ed.). Canadian edition.

[2] Canal, M. \& Swain, M.(1980).Theoretical bases of communicative approaches to second language teaching and testing. Applied Linguistics, 1, 1-47.

[3] Chris, B.(2010).The benefits of using drama in the ESL/EFL classroom. The Internet TESL Journal,vol xvi, No.1.

[4] A.Ika Handayanil, \& B.Siti Aisah, (2013).Student's meta- cognitive learning strategies toward speaking proficiency in EFL classes. Sultan Agenda Tirtaysa State UniversityBanten.

[5] Andrew D.Cohen, Susan J.Weaver, \& Tao-Yuanli (1996). The impact of strategies -based instruction on speaking a foreign language . Center of Advanced Research on Language Acquisition University of Minnesota.

[6] Brown,A.(1987).Metacognition, executive control, self-regulation, and other more mysterious mechanisms. In F.Weinert \& R.Kluwe (Eds.), Metacognition, motivation and understanding (PP.65-116).Hillside,

[7] Gaudart, H. (1992).Persuading students to speak in English. In Wijasuria, B. and Gaudart, H. (Eds), Teaching and Learning English in Challenging Situations.

[8] Holden, S. 1981. Drama in Language Teaching. Harlow: Longman.

[9] Huang, K. (2006).Metacognitive strategies in academic oral presentation. TESOL Paper. Province University Taiwan.

[10] Hymes,D. (1972).On communicative competence. In J.B.Pride and Holmes (eds)., Sociolinguistics, PP.269-93.Harmondsworth:Penguin NJ:Erlbaum.

[11] Holden, S. 1981. Drama in Language Teaching. Harlow: Longman.

[12] Jack,C. Richards, \& Willy, A.Renadye(2002).Méthodologie in Langage teaching .Cambridge University Press, USA.

[13] Krashen, S.D.,Long, M., \& Scarcella, R.(1982).Age, rate and eventual attainment in second language acquisition. In S.D .Krashen, R. Scarcella, \& M. Long (Eds.), Child-adult differences in second language acquisition (PP.175-201). Rowley,MA:Newbury house.

Katie, D.

(2016).Drama-based instruction activating learning through the arts. The University of Texas at Austin.

D.(2016).Drama based pedagogy, The university of Texas at Austin.

Kaite,

[16] Liu, N., \& Littlewood, W. (1997). Why do many students appear reluctant to participate in classroom learning discourse? System, 25(3), 371384.

[17] Mandie, M.M. (2004). Using Drama as an Effective Method to Teach Elementary

[18] Nelson, T.O. (1996).Consciousness and metacognition. Americn Psychologist, 51,102116.

[19] Mcleod, S.A. (2014).Les Vygotsky. Retrieved from www.simplypsychology.org/Vygotsky.html

[20] Pooneh, K. (2016). The effect of drama -based techniques as metacognitive pre-reading strategies on reading comprehension of pre-intermediate Iranian ESL learners. Research Journal of English Language and Literature, 4(3), 256-267. 
Bulletin de la Société Royale des Sciences de Liège, Vol. 86, special edition, 2017, p. 908 - 918

[21]

Rosalind,

M.F.(2012) .10 powerful benefits of using drama in the classroom, University of American Washington, DC, The Catholic

[22] Widdowson, H.G. (1978).Teaching language as communication. Oxford: Oxford University Press. 